communitarian aspect of refugee life is generally dismissed and often actively discouraged during protection and resettlement. The refugee's right and need to freely associate with members of his or her community is violated and overlooked.

Some of the flaws in the present system are experienced by countries of asylum. Perhaps most notably, there is no operationalized system of responsibility and burden sharing. Each country is responsible for its own determination system and providing

\section{Still another example of a flaw in the present system is that countries of the North spend an enormous amount of money on their own particular determination processes. This provides protection to only a small minority of the world's refugee population.}

protection to those refugees who enter their territory. For countries too impoverished to meet even the most basic needs of a refugee population, the UNHCR has undertaken to meet these needs. But the financing of the UNHCR is uncertain at best, meaning that the conditions in which refugee populations are required to live are often woefully inadequate. There is no consistent and coherent means of sharing the operational burdens that are part and parcel of refugee protection.

Against this backdrop, it is clear that a project which seeks to reformulate the international system for refugee protection is a noble endeavour. It will succeed only when the politicians see that somehow this new system is in their own interests. It will also be important to satisfy the dreamers, the visionaries, and the passionate advocates for justice and human rights. It is important to make it clear that the moral and ethical dimensions of the protection of refugees have been considered at every step.

Excerpts from the Five Studies in Action:

\title{
I. International Administration
}

\author{
Kathleen Newland and Galina Vitkovskaia
}

The authors were asked to consider the best means for international administration of the proposed reformed system of international refugee protection. They suggest that the UNHCR, in its present form, would not be able to administer the proposed system. They explore the possible shape of a successor organization, perhaps a revamped $U N H C R$, with secured levels of funding, a greater vesting of authority in regional bodies and an enhanced role for non-state actors, which would actively engage in refugee determination and allocation of responsibility for temporary protection among states. This is a substantially abbreviated version of the authors' original work. Please refer to the notice at the end of this section if you are interested in obtaining a full copy of the paper, which is expected to be published in mid-1996.

Neither states, nor refugees, nor the institutions that mediate between them can be wholly satisfied with the current system of international protection. It is arbitrary, expensive and uncertain in outcome. Its recent history has been one of ad hoc responses, some effective and some not, to a rapidly growing and changing set of demands. After forty-five years of experimentation, it is time to reassess the adequacy of the legal and institutional framework of international protection.

That a new system of refugee law should be internationally administered is one of the key operational concepts of the Reformulation Project, which proposes a central International

Kathleen Newland, Senior Associate, Carnegie Endowment for International Peace.

Professor Galina Vitkovskaia, Senior Researcher, Laboratory of Migration, Institute of Economic Forecasting, Russian Academy of Sciences.
Supervisory Authority to oversee the identification and protection of refugees. The three principal characteristics of the Authority are: 1) it would facilitate the operation and implementation of a new regime centered on human rights principles and operationally based on temporary protection rather than permanent asylum, 2) the diverse interests of the various major stakeholders in refugee issues would be represented (including states, refugee communities and nongovernmental organizations active in refugee affairs), and 3) a degree of equality in participation would allow each of the major actors to safeguard its interests in the system. The Authority would operate within a more general framework of respect for national and community values, consistency with the norms of international human rights law, and effective international burden sharing.

The Reformulation Project's goal of a universally accessible legal regime that offers a consistent degree of protection to refugees everywhere argues for a central (although not necessarily centralized) international refugee agency. An international refugee agency does, of course, exist, in the form of UNHCR. Should this be the agency to take on the administration of a reformulated system of refugee law? UNHCR in its present form has significant weaknesses that impede its functioning, many of which spring from the fiction that it is a temporary body. This is reflected in its financing (voluntary contributions), structure (not fully articulated below the level of High Commissioner and Executive Committee, and dependent on renewal of its mandate every five years), and culture (emergency and short-term oriented). Here we propose moving towards a 
more mature organization, renamed perhaps the United Nations Refugee Organization (UNRO). UNRO should not be thought of as a new organization, but as one that may evolve from the process of strengthening UNHCR.

UNRO would perform a number of functions not carried out by UNHCR. The most important of these are 1) centralized refugee status determination and 2) allocation among states of responsibility for temporary protection and the relocation of refugees to the designated sites. Centralized refugee status determination should be closely tied to the other proposed UNRO function of allocating responsibilities for and UNRO's role in effecting longterm solutions. Perhaps the major source of receiving countries' reluctance to offer temporary protection is skepticism about its temporariness. UNRO should articulate a norm of temporariness, of perhaps a maximum of five years, and have a mechanism for forwarding to bodies of the UN system or regional organizations a request for options for effecting solutions as the end of that period approaches.

UNRO would be composed of a General Council, Regional Commissions, issue-specific Advisory Committees, and a Secretariat. The General

\section{The Reformulation Project's goal of a universally accessible legal regime that offers a consistent degree of protection to refugees everywhere argues for a central (although not necessarily centralized) international refugee agency.}

protection. Without such bundling, some states may choose to hand over their costly determination procedures without accepting a share of responsibility for providing protection.

For even such a modest beginning of centralized allocation to find acceptance by states, a number of problems must be addressed. In the first place, handing people with valid refugee claims over to an international authority for removal without appeal may be incompatible with the laws of some states. Secondly, the quid pro quo for devolving some authority over protection admissions to UNRO would probably be for the agency to also take responsibility for, or at least cooperate actively in, the return of non-refugees. Third, while responsibility sharing will mean that refugees will not necessarily receive ongoing temporary protection in their country of first asylum, efforts should be made to avoid unnecessary transfers. This may mean, for example, exploring the viability of states accepting refugees beyond their allocated responsibility sharing quota in return for developmental or other assistance. Fourthly, is the question of the duration of temporary protection
Council would be the highest authority in UNRO. It would have authority to oversee the refugee protection process, but it would be primarily a policymaking body. The General Council would be composed of government representatives. Nongovernmental organizations should be granted consultative status. More formal representation for them, with voting power, is precluded by the difficulties of arriving at any truly representative arrangements for their participation. It would be easier to say which groups should be included in formal arrangements than which should not. An informal committee structure would give nongovernmental groups a voice in UNRO policy discussions. Most NGOs will continue to make their influence felt by acting on and through governments and intergovernmental bureaucracies, bringing to bear their advocacy, financial resources, information, ideas, labour and in some cases their electoral influence.

The General Council would be expected to delegate many of its powers to an Executive Committee, which would make decisions when the plenary body is not in session, and super- vise the Regional Commissions, the Secretariat, and the budget of the organization.

UNRO should be committed to vesting greater authority in regional bodies. Regional Commissions would oversee the quality of protection provided to refugees within their region. Issue-specific Advisory Committees might also be established. We would suggest a First Asylum Committee, to monitor admission to safety and nonrefoulement; an Emergency Response Committee to develop recommendations on early warning, preparedness and rapid response; a Temporary Protection Committee to monitor refugee rights and conditions in temporary asylum, as well as responsibility sharing; a Repatriation Committee concerned with the identification of opportunities for repatriation and dangers associated with it, which would also encourage the early establishment of Tripartite Committees for each refugee situation; and an Adjustment of Status Committee, to develop alternatives for refugees whose temporary protection goes on too long or who clearly cannot be expected to repatriate.

A positive strategy to strengthen the international administration of refugee protection should, in our view, be built on the following characteristics: gradual restructuring; service orientation; a combination of assessed, voluntary and subscription income; far-reaching consultative structures; consensus decision-making; more emphasis on regional fora; and stronger information gathering and analysis. There is little doubt that the international system of refugee protection is undergoing a process of profound change. This transition can take place deliberately, in a manner that protects the human rights of refugees as well as the interests of states. Or, it can proceed chaotically, converging toward a least common denominator of protection and obligation. The human costs of the latter would be terribly high; it would also take a toll on the structure of international cooperation built over the past fifty years. 